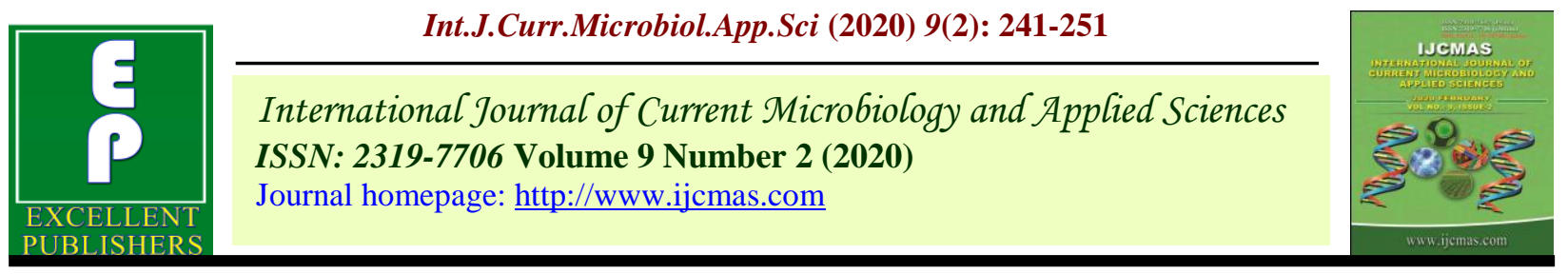

Original Research Article

https://doi.org/10.20546/ijcmas.2020.902.031

\title{
Direct Regeneration of Three Indian Maize Genotypes by Multiple Shoot Induction Using Split Nodes
}

\author{
D. P. Adarsha* and N. Nagesha \\ Department of Plant Biotechnology, College of Agriculture \\ University of Agricultural Sciences, GKVK, Bengaluru - 560 065, India \\ *Corresponding author
}

Keywords

Maize (Zea mays), Regeneration, Split nodes, Multiple shoots, Genotypes

Article Info

Accepted:

05 January 2020

Available Online:

10 February 2020

\section{A B S T R A C T}

Regeneration protocol is pre-requisite for the development of transgenic plants. Maize (Zea mays L) crop is severely affected by fungal disease turcicum leaf blight. In the present study, standardizing the regeneration protocol for maize genotype was carried for the development of transgenic maize against turcicum leaf blight. The direct regeneration of maize involved nodal explants from the maize coleoptiles. Three Turcicum leaf blight susceptible maize genotypes (NAI179, NAI193, and HKI413) were selected for this study. Different combinations of growth regulators were used with MS media to induce shoots and roots. The best responding explants for the shooting was recorded in NAI179 on $\mathrm{MS}+1.5 \mathrm{mgL}^{-1} \mathrm{BAP}$ media. Fastest responding genotype was found to be HKI413 on $\mathrm{MS}+0.5 \mathrm{mgL}^{-1} \mathrm{BAP}$ media. The maximum number of shoots were recorded in $\mathrm{NAI} 179$ on $\mathrm{MS}+\mathrm{mgL}^{-1} \mathrm{BAP}$ media and maximum shoot elongation was seen in $\mathrm{NAI} 193$ on $\mathrm{MS}+2.5 \mathrm{mgL}^{-1} \mathrm{BAP}+0.5 \mathrm{mgL}^{-1}$ IBA. The best response for rooting was observed in NAI179 on MS $+0.5 \mathrm{mgL}^{-1} \mathrm{BAP}+2.0 \mathrm{mgL}^{-1} \mathrm{NAA}$ media and fastest responding genotypes was found to be HKI413.

\section{Introduction}

Maize is the third most important cereal crop in the globe in terms food, fodder, and fuel. Production wise maize has significant figures globally and is often referred to as "Queen of Cereals" due to its wider adaptability and production. In the year 2017, the area occupied by maize in India was 9.47 million hectares with a production of 28.72 million MT and productivity of 3.03 t/ha (IIMR
\{Indian Institute of Maize Research\}), 2018). The global maize production was around 1040 million MT in the year 2017. The USA contributes 38 per cent of maize production followed by China and Brazil with 23 per cent and 9 per cent respectively. India contributes 2 per cent of global maize production. Global productivity of maize is estimated to be around $5.6 \mathrm{t} / \mathrm{ha}$. The USA tops productivity followed by Canada and Ukraine (India Maize Summit, 2017, Anonymous). In India, 
Karnataka is the largest producer of maize. It produces around 16 per cent of total maize in the country followed by Telangana and Bihar.

Maize is continuously challenged by biotic and abiotic stresses in the field. Traditional breeding programs have failed in recent times to develop resistant and tolerant verities to such stresses. Use of molecular and biotechnology techniques like genetic transformation is indispensable to save time and produce an effective variety. Thus, efficient in vitro regeneration techniques using various explants, culture conditions and hormonal combinations are required. This helps in more effective production of pure lines in maize than conventional breeding. This enhances the development and performance of high yielding hybrids. Variations form the soma-clones are useful for genetic material exchange in wide hybrids. Development of disease-free plants can be regenerated through meristem culture. This is very important in the elimination of virus and viroid. This helps significantly to increase yield (Ahsan et al., 1988). Green et al., (1974) first reported regeneration of maize from immature embryos. Since then, maize regeneration has been reported from immature embryos, mature embryos (Huang and Wei, 2004; Al-Abed et al., 2006), nodal regions (Vladimir et al., 2006), leaf tissues, anther, tassel and meristem, protoplast and shoot meristem (Sairam et al., 2003). Murashige and Skoog media is the most common regeneration media used in maize regeneration. BAP is most successful growth regulator to induce multiple shoots in various maize explants including the nodes used in this study.

Immature embryos are predominantly used for establishing regeneration-competent cells or callus cultures for genetic transformation. To harness the benefits of genetic transformation in the breeding program under tropical and subtropical Indian climatic conditions, it is important to develop protocols of regeneration and transformation for Indian maize inbreds (Ahmadabadi et al., 2006). Presently, immature embryos are mostly used as a source of explants to establish regeneration and competent callus cultures in maize (Manivannan et al., 2010). Use of immature embryos as explants is laborious as well as time-consuming. For round-the-year availability of immature embryos, a growth chamber, as well as staggered planting of the crop, is essentially required. Alternatively, embryos from mature seeds can be an excellent source as explants which is easy to handle, available year-round and in bulk quantities. Report available for the induction of regenerable callus and development of whole plants from the genotypes adapted to sub-tropical conditions of the Indian subcontinent is very meagre.

In this study, we report an effective regeneration protocol using mature seeds germinated to produce split nodes. These split nodes were used as explants in shoot induction media to produce multiple shoots (Fig 1). Three Turcicum leaf blight susceptible maize genotypes (NAI179, NAI193, and HKI413) were selected for this study. BAP was used to induce multiple shoots and NAA was used to induce rooting.

\section{Materials and Methods}

\section{Planting material and seed sterilization}

The seeds of three maize genotypes (NAI179, NAI193 and HKI413) used in this study were obtained from the Department of Genetics and Plant Breeding, College of Agriculture, VC Farm, Mandya (Karnataka). Mature maize seeds were kept in running water overnight. Next morning seeds were treated with fungicide i.e. 1 per cent Bavistin (Carbendazim 50 per cent WP) solution for 1 
hour. Then the seeds were washed thrice with double distilled water. After all the traces were removed seeds were taken inside presterilized LAF chamber. Inside the chamber, seeds were treated with 70 per cent ethanol for 2 minutes and 0.1 per cent mercuric chloride $\left(\mathrm{HgCl}_{2}\right)$ for 15 mins. To remove the traces of sterilant, seeds were washed in autoclaved distilled water for 6 times. After this seeds were allowed to dry on a sterile blotting paper for 15 minutes.

\section{Seed germination and preparation of explant}

The seeds were inoculated on basal MS media with the embryo axis on the media surface at a rate of 5 seeds per plate and incubated in the culture room at temperature of $24+2^{0} \mathrm{C}$. Seven to ten-day old seedlings were selected to dissect the explant. Inside the LAF the coleoptile was excised with half a centimetre above and below the node using a sterile scalpel. Such successfully excised nodes were longitudinally cut into two halves. This split node was used as explant for direct regeneration.

\section{Multiple shoot regeneration and elongation}

The split node was inoculated on the shooting media consisting of MS media supplemented with BAP at six different concentrations $(0.5$, $1.0,1.5,2.0,2.5,3.0 \mathrm{mg} / \mathrm{L}-$ Table 1$)$ to induce multiple micro-shoots. The split nodes were inoculated on the media such that the exposed meristematic cells were in contact with shoot induction media. Two explants were inoculated per each plate. Plates were incubated in growth chamber at a temperature of $24+1{ }^{0} \mathrm{C}$ under fluorescence light for 16 hours and 8 hours dark. Regular sub-culturing was done to each responding cultures for every $15^{\text {th }}$ day from the date of inoculation. Plates with multiple shoots were excised and single micro shoots were transferred into new media bottles with the same hormone (BAP) concentration along with IBA for shoot elongation (Table 2).

\section{Rooting and hardening}

Media bottles with well-established shoots with desirable length were picked and shoots from such bottles were transferred to rooting media with different concentration of auxins (NAA and IBA- Table 3). After inoculation, bottles were kept inside the culture room under dark condition until rooting was induced.

Bottles with well-established roots were selected and taken inside the LAF. Plants were carefully removed from the media and washed with autoclaved distilled water. Then the plants were immersed in the test tube containing pre-hardening MS solution (Half MS media without agar) to get rid of all the traces of agar medium. Next day plants were transferred to paper cups consisting of primary hardening mix. The mix consisted of sand, peat, and vermicompost in equal ratio. All the components of the mix were autoclaved before use. The cups used were exposed to UV light before use. The plants in the cups were covered with plastic covers with few holes and transferred to the culture room. Plants in the cups were observed every day and sprayed with half MS media without sucrose agar.

Since all the experiment was conducted at controlled conditions like temperature, relative humidity, $\mathrm{pH}$, etc., $\mathrm{CRD}$ was the best experimental design possible. Since the study dealt with two factors (variables) genotype and growth media a two-factorial complete randomized design (FCRD) was engaged for the study. All the observations were analysed using OPSTAT online analysis tool (http://14.139.232.166/opstat/). 


\section{Results and Discussion}

A standard regeneration protocol becomes at most important when a research is focused on genetic improvement of the crop with genetic transformation and transgenic technology. The present study focuses on three important inbred lines (NAI179, NAI193 and HKI413) in maize which are susceptible genotypes of fungal diseases in maize. The present study has been done to standardize a direct regeneration protocol in these genotypes by utilizing mature seeds.

Regeneration response can be accounted for differences in the internal hormone level within each explant (Norstong et al., 1970; Bhaskaran and Smith, 1990). Genotypes response to shooting induction showed a significant difference with each other. The highest response was recorded on NAI179 genotype (82.33 per cent) followed byHKI413 (64.27 per cent). The lowest response was observed in NAI193 (49.89 per cent). No significant difference was seen among the treatment adopted for this study for shooting response. However, highest response was recorded in (Shoot Induction Medium) SIM3 $\left(\mathrm{MS}_{0}+1.5 \mathrm{mgL}^{-1}\right.$ BAP) (74 per cent) and lowest response was in SIM2 $\left(\mathrm{MS}_{0}+1.0\right.$ $\mathrm{mgL}^{-1}$ BAP) with 57.34 per cent response. These results revealed that there is no significance for different cytokinin concentration on the response to regenerate. The possible explanation for these results may be that the explants are competent enough due to totipotency in plants (Huang and Wei. 2004). It can be assumed that the response is pre-determined by the initial basal MS media in which the seeds of the explants were germinated. A significant difference was observed for the interaction effect of genotype and treatment. Highest response for regeneration response was observed in the genotype NAI179 (88.67 per cent) on a media SIM4 $\left(\mathrm{MS}_{0}+2.0 \mathrm{mgL}^{-1} \mathrm{BAP}\right)$. The limited response was observed in the genotype NAI193 on SIM5 media $\left(\mathrm{MS}_{0}+2.5 \mathrm{mgL}^{-1}\right.$ BAP).

Response to regeneration in maize is highly genotype dependent. The possible reason for the reduced response in NAI 193 was due to recalcitrance. Recalcitrant seeds tend to have low frequency in responding to the MS media supplemented with BAP (Bohorova et al., 1995). Genotype of the plant is very critical on the response of the explant. Significant variation was observed among the genotypes for the number of days they took to respond on the shooting media. The lowest number of days was observed in HKI413 genotypes (3.78 days) followed by NAI193 (5.5 days). The highest number of days was recorded in NAI179 genotypes which responded after 5.61 days. The effect of media significantly differed for the number of days for shooting. The fastest responding media was SIM1 $\left(\mathrm{MS}_{0}\right.$ $+0.5 \mathrm{mgL}^{-1}$ BAP) followed bySIM5 $\left(\mathrm{MS}_{0}\right.$ $\left.+2.5 \mathrm{mgL}^{-1} \mathrm{BAP}\right)$ and SIM6 $\left(\mathrm{MS}_{0}+3 \mathrm{mgL}^{-1}\right.$ BAP). SIM4 $\left(\mathrm{MS}_{0}+2.0 \mathrm{mgL}^{-1} \mathrm{BAP}\right)$ media responded the slowest (7.11 days). Media composition is the most important factor affecting maize tissue culture (Frame et al., 2006; Binott et al., 2008). The response to the same explant varies within the genotype at a greater extent (Henry et al., 1994). As suggested by Rakshith et al., (2010) it is very evident from the results of this experiment that for a reproducible regeneration protocol an efficient media source and genotype is a must. The fastest responding genotype was HKI413 (2 days) on SIM6 media $\left(\mathrm{MS}_{0}+3.0\right.$ $\left.\mathrm{mgL}^{-1} \mathrm{BAP}\right)$. The slowest interaction was in NAI179 (7.3 days) on SIM4 media $\left(\mathrm{MS}_{0}+2.0\right.$ $\left.\mathrm{mgL}^{-1} \mathrm{BAP}\right)$.

BAP is the most common choice among researchers to regenerate multiple shoots in cereal plants. The effect of genotype on the number of shoots in the study showed a significant difference (Table 4). NAI179 
genotype showed the significantly highest number of micro-shoots (2.94 shoots) per explant followed by HKI413 (2.83 shoots) and NAI 193 (2.33 shoots). In the present study, NAI179 came up as the best genotype to obtain a maximum number of explants. It is observed that there is a strong interaction effect between the genotype and age of the plant. All the nodal explant used in the present study ranged from 7 to 14 days old. BAP is the most common cytokinin for maize (Sahoo et al., 2002). Interaction between genotype and media showed a significant difference. The genotype NAI179 recorded the maximum number of shoots ( 4 shoots) per explant on the media SIM3 $\left(\mathrm{MS}_{0}+1.5 \mathrm{mgL}^{-1}\right.$ BAP) and SIM6 $\left(\mathrm{MS}_{0}+3.0 \mathrm{mgL}^{-1} \mathrm{BAP}\right)$. A minimum number of shoots were observed in NAI193 genotype on the SIM4 $\left(\mathrm{MS}_{0}+2.0\right.$ $\mathrm{mgL}^{-1}$ BAP) media. These findings made the fact evident that the frequency of shoots is more concentrated on BAP. The results are in agreement with work done by Ward and Jordan (2001). Best genotypic and media indication was observed between Va35 inbred line and MS media with $1.5 \mathrm{mgL}^{-1} \mathrm{BAP}$ compared with N6 media (Gorji et al., 2011) this experiment agrees with results of our study.

Cytokinins are the plant hormones which have a prime role in shoot elongation in vitro
(Mushke et al., 2016). A significant difference was observed on the shoot length among the three genotypes (Table 5). Longest shoots were observed in the genotype NAI193 $(8.38 \mathrm{~cm})$ followed by NAI179 $(7.50 \mathrm{~cm})$ and shortest in HKI413 (7.34 cm). The observation from our study indicates that the length of shoots under regeneration is genotype dependent. It may be due to the endogenous hormone that was present in the explant at the time of inoculation (Norstong et al., 1970; Bhaskaran and Smith 1990). Effect of media treatment varied significantly on the shoot length. The SM5 media $\left(\mathrm{MS}_{0}+2.5\right.$ $\mathrm{mgL}^{-1} \mathrm{BAP}+0.5 \mathrm{mgL}^{-1}$ IBA) showed significantly higher shoot length $(9.44 \mathrm{~cm})$ followed by SM4 $\left(\mathrm{MS}_{0}+2.0 \mathrm{mgL}^{-1} \mathrm{BAP}+0.5\right.$ $\mathrm{mgL}^{-1}$ IBA). The shortest shoot length was observed on SIM2 media $\left(\mathrm{MS}_{0}+1.0 \mathrm{mgL}^{-1}\right.$ BAP $+0.5 \mathrm{mgL}^{-1}$ IBA). Different hormonal concentration with different media for different genotypes affects the shoot elongation and creates dissimilarity (Morshed et al., 2014). Interaction between genotype and media varied significantly. Maximum shoot length was observed in the genotype NAI193 $(10 \mathrm{~cm})$ on the media SIM5 $\left(\mathrm{MS}_{0}\right.$ $\left.+2.5 \mathrm{mgL}^{-1} \mathrm{BAP}+0.5 \mathrm{mgL}^{-1} \mathrm{IBA}\right)$. Lowest shoot length was observed in HKI413 genotype on SIM2 media $\left(\mathrm{MS}_{0}+1.0 \mathrm{mgL}^{-1}\right.$ $\left.\mathrm{BAP}+0.5 \mathrm{mgL}^{-1} \mathrm{IBA}\right)$.

Table.1 Treatments to induce multiple shoots from the split node of maize (Shoot Induction Media)

\begin{tabular}{|l|c|c|}
\hline $\begin{array}{l}\text { Sl. } \\
\text { No. }\end{array}$ & Shoot induction medium & $\begin{array}{c}\text { Treatment } \\
\text { The concentration of growth regulator }\end{array}$ \\
\hline $\mathbf{1}$ & SIM1 & $\mathrm{MS}_{0}+0.5 \mathrm{mLL}^{-1} \mathrm{BAP}$ \\
\hline $\mathbf{2}$ & SIM2 & $\mathrm{MS}_{0}+1.0 \mathrm{mLL}^{-1} \mathrm{BAP}$ \\
\hline $\mathbf{3}$ & SIM3 & $\mathrm{MS}_{0}+1.5 \mathrm{mLL}^{-1} \mathrm{BAP}$ \\
\hline $\mathbf{4}$ & SIM4 & $\mathrm{MS}_{0}+2.0 \mathrm{mLL}^{-1} \mathrm{BAP}$ \\
\hline $\mathbf{5}$ & SIM5 & $\mathrm{MS}_{0}+2.5 \mathrm{mLL}^{-1} \mathrm{BAP}$ \\
\hline $\mathbf{6}$ & SIM6 & $\mathrm{MS}_{0}+3.0 \mathrm{mLL}^{-1} \mathrm{BAP}$ \\
\hline
\end{tabular}


Table.2 Treatments used for sub-culturing micro shoots (Shooting media)

\begin{tabular}{|l|c|c|}
\hline $\begin{array}{l}\text { Sl. } \\
\text { No. }\end{array}$ & Shooting medium & $\begin{array}{c}\text { Treatment } \\
\text { (Concentration and combination of growth regulator) }\end{array}$ \\
\hline $\mathbf{1}$ & $\mathrm{SM} 1$ & $\mathrm{MS}_{0}+0.5 \mathrm{mgL}^{-1} \mathrm{BAP}+0.5 \mathrm{mgL}^{-1} \mathrm{IBA}$ \\
\hline $\mathbf{2}$ & $\mathrm{SM} 2$ & $\mathrm{MS}_{0}+1.0 \mathrm{mgL}^{-1} \mathrm{BAP}+0.5 \mathrm{mgL}^{-1} \mathrm{IBA}$ \\
\hline $\mathbf{3}$ & $\mathrm{SM} 3$ & $\mathrm{MS}_{0}+1.5 \mathrm{mgL}^{-1} \mathrm{BAP}+0.5 \mathrm{mgL}^{-1} \mathrm{IBA}$ \\
\hline $\mathbf{4}$ & $\mathrm{SM} 4$ & $\mathrm{MS}_{0}+2.0 \mathrm{mgL}^{-1} \mathrm{BAP}+0.5 \mathrm{mgL}^{-1} \mathrm{IBA}$ \\
\hline $\mathbf{5}$ & $\mathrm{SM} 5$ & $\mathrm{MS}_{0}+2.5 \mathrm{mgL}^{-1} \mathrm{BAP}+0.5 \mathrm{mgL}^{-1} \mathrm{IBA}$ \\
\hline $\mathbf{6}$ & $\mathrm{SM} 6$ & $\mathrm{MS}_{0}+3.0 \mathrm{mgL}^{-1} \mathrm{BAP}+0.5 \mathrm{mgL}^{-1} \mathrm{IBA}$ \\
\hline
\end{tabular}

Table.3 Treatments used in rooting media

\begin{tabular}{|c|c|c|}
\hline Sl. No. & Rooting medium & $\begin{array}{c}\text { Treatment } \\
\text { Concentration and combination of growth regulator }\end{array}$ \\
\hline $\mathbf{1}$ & $\mathrm{RM} 1$ & $\mathrm{MS}_{0}+0.5 \mathrm{mgL}^{-1} \mathrm{BAP}+0.5 \mathrm{mgL}^{-1} \mathrm{NAA}$ \\
\hline $\mathbf{2}$ & $\mathrm{RM} 2$ & $\mathrm{MS}_{0}+0.5 \mathrm{mgL}^{-1} \mathrm{BAP}+1.0 \mathrm{mgL}^{-1} \mathrm{NAA}$ \\
\hline $\mathbf{3}$ & $\mathrm{RM} 3$ & $\mathrm{MS}_{0}+0.5 \mathrm{mgL}^{-1} \mathrm{BAP}+1.5 \mathrm{mgL}^{-1} \mathrm{NAA}$ \\
\hline $\mathbf{4}$ & $\mathrm{RM} 4$ & $\mathrm{MS}_{0}+0.5 \mathrm{mgL}^{-1} \mathrm{BAP}+2.0 \mathrm{mgL}^{-1} \mathrm{NAA}$ \\
\hline $\mathbf{5}$ & $\mathrm{RM} 5$ & $\mathrm{MS}_{0}+0.5 \mathrm{mgL}^{-1} \mathrm{BAP}+0.2 \mathrm{mgL}^{-1} \mathrm{IBA}$ \\
\hline $\mathbf{6}$ & $\mathrm{RM} 6$ & $\mathrm{MS}_{0}+0.5 \mathrm{mgL}^{-1} \mathrm{BAP}+0.4 \mathrm{mgL}^{-1} \mathrm{IBA}$ \\
\hline $\mathbf{7}$ & $\mathrm{RM} 7$ & $\mathrm{MS}_{0}+0.5 \mathrm{mLL}^{-1} \mathrm{BAP}+0.6 \mathrm{mgL}^{-1} \mathrm{IBA}$ \\
\hline $\mathbf{8}$ & $\mathrm{RM}$ & $\mathrm{MS}_{0}+0.5 \mathrm{mgL}^{-1} \mathrm{BAP}+1.8 \mathrm{mgL}^{-1} \mathrm{IBA}$ \\
\hline
\end{tabular}

Table.4 Effect growth regulators BAP on multiple shoot induction

\begin{tabular}{|c|l|l|l|l|l|l|l|l|l|}
\hline $\begin{array}{c}\text { BAP } \\
\text { (mg/L) }\end{array}$ & \multicolumn{3}{|c|}{$\begin{array}{c}\text { Per cent Response } \\
\text { Per explant }\end{array}$} & \multicolumn{3}{c|}{$\begin{array}{c}\text { No. of days for } \\
\text { Shooting }\end{array}$} & \multicolumn{3}{c|}{$\begin{array}{c}\text { No. of shoots per } \\
\text { Explant }\end{array}$} \\
\hline Genotype & NAI179 & NAI193 & HKI413 & NAI179 & NAI193 & HKI413 & NAI179 & NAI193 & HKI413 \\
\hline $\mathbf{0 . 5}$ & 83.34 & 41.67 & 83.34 & 5.00 & 1.33 & 2.34 & 3.34 & 2.33 & 4.00 \\
\hline $\mathbf{1 . 0}$ & 83.34 & 55.34 & 33.34 & 5.00 & 7.67 & 4.33 & $2 . .67$ & 1.67 & 1.31 \\
\hline $\mathbf{1 . 5}$ & 83.34 & 55.34 & 83.34 & 5.33 & 7.37 & 5.34 & 4.00 & 4.66 & 3.00 \\
\hline $\mathbf{2 . 0}$ & 88.67 & 50.00 & 33.34 & 7.34 & 8.33 & 5.6 & 2.33 & 1.33 & 2.00 \\
\hline $\mathbf{2 . 5}$ & 55.34 & 33.34 & 88.67 & 5.34 & 4.34 & 3.00 & 1.33 & 2.00 & 4.67 \\
\hline $\mathbf{3 . 0}$ & 100.00 & 63.37 & 38.67 & 5.67 & 5.67 & 2.00 & 4.00 & 2.00 & 2.00 \\
\hline SE & Genotype & Media & G X M & Genotype & Media & G X M & Genotype & Media & G X M \\
\hline & 4.9 & 7.02 & 12.17 & 0.56 & 0.8 & 1.38 & 0.19 & 0.27 & 0.47 \\
\hline
\end{tabular}


Table.5 Effects of growth regulators on shooting

\begin{tabular}{|c|c|c|c|c|}
\hline \multirow{2}{*}{ Growth regulators $(\mathbf{m g} / \mathbf{L})$} & \multicolumn{3}{|c|}{ Shoot Length } \\
\hline BAP & IBA & NAI179 & NAI193 & HKI413 \\
\hline $\mathbf{0 . 5}$ & 0.5 & 9.34 & 8.00 & 5.66 \\
\hline $\mathbf{1 . 0}$ & 0.5 & 6.00 & 9.00 & 5.00 \\
\hline $\mathbf{1 . 5}$ & 0.5 & 7.66 & 6.66 & 9.16 \\
\hline $\mathbf{2 . 0}$ & 0.5 & 10.00 & 7.16 & 9.16 \\
\hline $\mathbf{2 . 5}$ & 0.5 & 4.33 & 10.00 & 8.33 \\
\hline $\mathbf{3 . 0}$ & 0.5 & 7.50 & 9.50 & 6.66 \\
\hline Standard Error & Genotype & Media & G X M \\
\hline & & 0.24 & 0.34 & 0.59 \\
\hline
\end{tabular}

Table.6 Effect of growth regulators on rooting

\begin{tabular}{|c|c|l|l|l|l|l|l|}
\hline $\begin{array}{c}\text { Growth regulators } \\
(\mathbf{m g} / \mathbf{L})\end{array}$ & \multicolumn{3}{c|}{ Per cent response } & \multicolumn{3}{c|}{ No. of days for rooting } \\
\hline NAA & BAP & NAI179 & NAI193 & HKI413 & NAI179 & NAI193 & HKI413 \\
\hline $\mathbf{0 . 5}$ & 0.5 & 50.00 & 75.00 & 52.67 & 15.00 & 16.67 & 15.00 \\
\hline $\mathbf{0 . 5}$ & 1.0 & 100.00 & 50.00 & 27.67 & 19.00 & 18.34 & 15.00 \\
\hline $\mathbf{0 . 5}$ & 1.5 & 75.0 & 75.00 & 52.67 & 18.33 & 18.33 & 18.00 \\
\hline $\mathbf{0 . 5}$ & 2.0 & 100.0 & 100.00 & 100.00 & 17.00 & 15.67 & 15.33 \\
\hline Standard Error & Genotype & Media & G X M & Genotype & Media & G X M \\
\hline & & 8.95 & 10.33 & 17.9 & 0.52 & 0.6 & 1.05 \\
\hline
\end{tabular}

Table.7 Hardening of three genotypes of maize plants produced in vitro

\begin{tabular}{|l|c|c|}
\hline Genotype & No. of Plants & $\begin{array}{l}\text { No. of plants survived } \\
\text { after primary hardening }\end{array}$ \\
\hline NAI179 & 12 & 5 \\
\hline NAI193 & 12 & 7 \\
\hline HKI413 & 12 & 3 \\
\hline
\end{tabular}


Fig.1 A brief outline of direct regeneration of maize plants using split node as explant

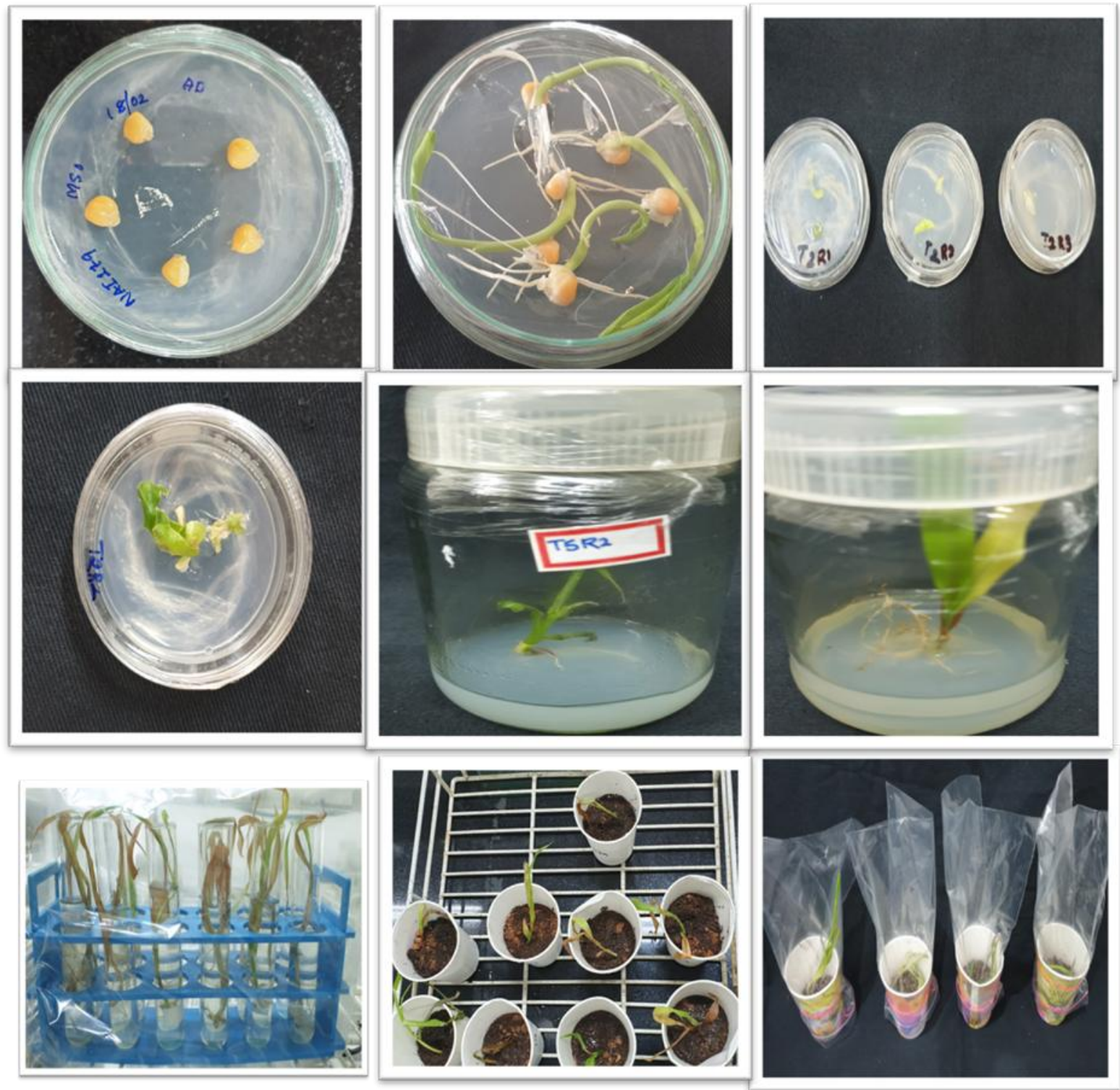

When we investigate the close work on root induction in maize, the MS media supplemented with activated charcoal along with growth regulators (Chen et al., 2012) would induce more rooting or the cultures were kept in the dark condition for a longer period than usual (Pathi et al., 2013). Except for the rooting hormone, none of the conditions were provided to the plants in this study. However, it is important to consider the fact that only small number of maize genotypes has regeneration capacity in vitro, thus there is a potential difference within the genotypes to respond for rooting (Armstrong and Green, 1985).

NAI179 genotype showed the highest rooting response (81.25) followed by NAI193 (75.00) (Table 6). The lowest response was observed in HKI413 (58.25). RM4 media $\left(\mathrm{MS}_{0}+0.5\right.$ $\left.\mathrm{mgL}^{-1} \mathrm{BAP}+2.0 \mathrm{mgL}^{-1} \mathrm{NAA}\right)$ showed significantly highest response to rooting (100) followed by RM3 $\left(\mathrm{MS}_{0}+0.5 \mathrm{mgL}^{-1} \mathrm{BAP}+\right.$ $\left.1.5 \mathrm{mgL}^{-1} \mathrm{NAA}\right)$. Lowest response was 
observed on RM1 media $\left(\mathrm{MS}_{0}+0.5 \mathrm{mgL}^{-1}\right.$ $\mathrm{BAP}+0.5 \mathrm{mgL}^{-1} \mathrm{NAA}$ ) which showed 59.22 per cent response. The best NAA concentration for root induction in maize is $1.5 \mathrm{mgL}^{-1}$ NAA. Highest response was observed in the genotype NAI179 (100) on RM4 media $\left(\mathrm{MS}_{0}+0.5 \mathrm{mgL}^{-1} \mathrm{BAP}+2.0\right.$ $\left.\mathrm{mgL}^{-1} \mathrm{NAA}\right)$. Two weeks for rooting response is late when compared to other studies.

This might be due to under utilization activated charcoal in the media in the present study. Usually maize the shoots start producing phenols as they age which inhibits the auxin activity (Ramakrishnan et al., 2014). The genotype HKI413 took the shortest time to rooting (15.38 days) and the genotype NAI179 recorded the longest time for rooting (17.33 days). The media treatment RM1 $\left(\mathrm{MS}_{0}+0.5 \mathrm{mgL}^{-1} \mathrm{BAP}+0.5 \mathrm{mgL}^{-1}\right.$ NAA) showed the shortest time for rooting (15.56 days) and longest time was observed on $\mathrm{RM} 3$ media $\left(\mathrm{MS}_{0}+0.5 \mathrm{mgL}^{-1} \mathrm{BAP}+1.5\right.$ $\left.\mathrm{mgL}^{-1} \mathrm{NAA}\right)$. But the best combination was for the genotype HKI413 on the media RM1 $\left(\mathrm{MS}_{0}+0.5 \mathrm{mgL}^{-1} \mathrm{BAP}+0.5 \mathrm{mgL}^{-1} \mathrm{NAA}\right)$ which showed rooting in 15.55 days. Eventually, any regeneration is complete only after the plant is finally established in the greenhouse which can be used for other downstream processes. Plants under hardening must bear a sudden shift in the mode of nutrition from heterotrophic to autotrophic mode. Such plant's physiology tends to be uneven. This may lead the plant vulnerable to severe biotic and abiotic stress which was dealt with care in the study. The detail of number of plants survived during hardening is mentioned in the Table 7.

In conclusion, the regeneration method standardized in the present investigation relies on the fact that it is quick and used mature seeds as explant which ensures year-round availability which might beuseful for genetic transformation studies. In this study, we have used mature seed asa novel explant and the regeneration was achieved through multiple shoot regeneration from split nodes. The best responding explants for the shooting was recorded in NAI179 on $\mathrm{MS}+1.5 \mathrm{mgL}^{-1} \mathrm{BAP}$ media. Fastest responding genotype was found to be HKI413 on MS + 0.5 $\mathrm{mgL}^{-1} \mathrm{BAP}$ media. The maximum number of shoots were recorded in NAI179 on $\mathrm{MS}+1.5 \mathrm{mgL}^{-1} \mathrm{BAP}$ media and maximum shoot elongation was seen in NAI193 on $\mathrm{MS}+2.5 \mathrm{mgL}^{-1} \mathrm{BAP}+$ $0.5 \mathrm{mgL}^{-1}$ IBA. The best response for rooting was observed in NAI179 on MS + $0.5 \mathrm{mgL}^{-1}$ $\mathrm{BAP}+2.0 \mathrm{mgL}^{-1} \mathrm{NAA}$ media and fastest responding genotypes was found to be HKI413. The development of multiple selfgrowing shoot buds indicates several independent transgenic events which can be potentially useful to screen out the performance of transgenic in vitro. As per our knowledge, no such reports have been discussed regarding the use of genotypes in maize which are susceptible to major fungal diseases. This investigation will be thus a greater use for crop improvement in maize involving fungal resistance.

\section{References}

Ahmadabadi, M., Ruf, S. and Bock, R., 2007, A leaf-based regeneration and transformation system for maize (Zea mays L.). Transgenic Res., 16: 437-448. Ahsan, M., Mehdi, S. S. and Khaliq, I., 2000, Tissue culture and breeding of maize (Zea mays L.) A review. Pak. J. Biol. Sci., 3: 1985-1988.

Al-Abed, D., Rudrabhatla, S., Talla, R. and Goldman, S., 2006, Split-seed: a new tool for maize researchers. Planta, (6): 1355-1360.

Armstrong C. L. and Green C. E., 1985, Establishment and maintenance of friable, embryogenic maize callus and involvement of L-Proline. Planta, 164:207- 214. 
Bhaskaran, S., and Smith, R.H., 1990, Regeneration in cereal tissue culture. Crop Sci., 30: 1328-1336.

Binott, J.M. Songa, J. Ininda, E.M. Njagi and J. Machuka, 2008, Plant regeneration from immature zygotic embryos of Kenyan maize inbred lines and their respective single cross hybrids through somatic embryogenesis. Afr. J. Biotechnol. 7: 981.

Bohorova, N. E., Luna, B., Brito, R. M., Huerta, L. D. and Hoisington, D. A., 1995, Regeneration potential of tropical-subtropical-mid altitude and highland maize inbreds [Mexico]. Maydica (Italy).

Chen, X. W., Shao, L., Liang, L. and Pan, Z. T., 2012, Effect of activated charcoal on rooting in tissue culture seedling of Begonia fimbristipula on Dinghushan Mountain. Journal of Chinese Medicinal Materials (Zhong Yao Cai), 35(9): 1369-1373.

Frame, B. R., Mcmurray, J. M., Fonger, T. M., Main, M. L., Taylor, K. W., Torney, F. J., and Wang, K., 2006, Improved Agrobacterium-mediated transformation of three maize inbred lines using MS salts. Plant cell reports, 25(10): 10241034.

Gorji, A. H., Zolnoori, M., Jamasbi, A. and Zolnoori, Z., 2011, In vitro plant generation of tropical maize genotypes. In International Conference on Environmental, Biomedical and Biotechnology IPCBEE., 16: 52-59.

Green C.E., Phillips R.L. and Kleese R.A., 1974, Tissue culture of maize (Zea mays L.): initiation, maintenance, and organic growth factors. Crop Sci., 14:54-58.

Henry, Y., Vain, P. and De-Buyser, J., 1994, Genetic analysis of in vitro plant tissue culture responses and regeneration capacities. Euphytica. 79: 45-58.

Huang X. O. and Wei Z. M., 2004, High- frequency plant regeneration through callus initiation from mature embryos of maize (Zea mays L.). Plant Cell Rep., 22: 793-800.

Manivannan, A., Kaul, J., Singode, A. and Dass, S., 2010, Callus induction and regeneration of elite Indian maize inbreds. Afr. J. Biotechnol., 9(44):74467452.

Morshed, S., Siddique, A. B., and Islam, S. S., 2014, Efficient plant regeneration using mature and immature embryos of maize (Zea mays L.). Int. J. Agric. Innov. Res. 3: 895-904.

Mushke, R., Yarra, R., and Bulle, M., 2016, Efficient in vitro direct shoot organogenesis from seedling derived split node explants of maize (Zea mays L.). J Genet Eng Biotechnol., 14:49-53.

Norstong, K., 1970, Induction of embryo like structures by kinetin in cultured barley embryos. Dev Biol. 23:665-670

Pathi, K. M., Tula, S., Huda, K. M. K., Srivastava, V. K. and Tuteja, N., 2013, An efficient and rapid regeneration via multiple shoot induction from mature seed derived embryogenic and Organogenic callus of Indian maize (Zea mays L.). Plant Signal. Behav. 8(10): 25891.

Rakshit, S., Rashid, Z., Sekhar, J. C., Fatma, T. and Dass, S., 2010, Callus induction and whole plant regeneration in elite Indian maize (Zea mays L.) in breds. Plant Cell, Tiss Org., 100(1): 31-37.

Ramakrishnan, M., Ceasar, S. A., Duraipandiyan, V. and Ignacimuthu, S., 2014, Efficient plant regeneration from shoot apex explants of maize (Zea mays) and analysis of genetic fidelity of regenerated plants by ISSR markers. Plant Cell, Tiss. Org., 119(1): 183-196

Sahoo, H., Frame B., Whitham S. and Wang K., 2004, Assessment of transgenic maize events produced by particle 
bombardment or Agrobacterium mediated transformation. Mol. Breed., 13: 201-208.

Sairam, R.V., Parani, M., Franklin, G., Lifeng, Z., Smith, B., Macdougall, J., Wilber, C., Shekhi, H., Kashikar, N., Meeker, K., Al-Abed, D., Berry, K., Vierling, R. and Goldman, S. L., 2003, Shoot meristem: an ideal explant for Zea mays L. transformation. Genome, 46:323-329.
Vladimir, S., Gilbertson, L., Adae, P., Duncan, D., 2006, Agrobacteriummediated transformation of seedlingderived maize callus. Plant Cell Rep. 25:320-328.

Ward, K.A. and Jordan, M.C., 2001, Callus formation and plant regeneration from immature embryos of rye (Secale cereale L.). In Vitro Cell Dev. Biol. Plant., 37: 361-368.

\section{How to cite this article:}

Adarsha, D. P. and Nagesha, N. 2020. Direct Regeneration of Three Indian Maize Genotypes by Multiple Shoot Induction Using Split Nodes. Int.J.Curr.Microbiol.App.Sci. 9(02): 241-251. doi: https://doi.org/10.20546/ijcmas.2020.902.031 